\title{
DE AFVOER DER OMBILIEN-STEENKOLEN.
}

Reeds meermalen werd in dit Tijdschrift de aandacht gevestigd op den rijken kolenschat langs de oevers der Ombilien en op de verschillende onderzoekingen in het werk gesteld om den afvoer dier kolen te verzekeren.

Ik heb hierin vrijheid gevonden, om dit onderwerp - naar aanleiding der jongste beschouwingen - nogmaals in de Economist ter sprake te brengen.

De behoefte aan stoomkolen in den Indischen Archipel neemt dagelijks toe en zal bij uitbreiding der stoomvaart en van de Java-spoorwegen nog vermeerderen.

De laatste onderzoekingen der mijn-ingenieurs hebben, wel is waar, de aanwezigheid van steenkolen op andere vindplaatsen aangewezen, maar die kolenbeddingen komen, hetzij door de kleine hoeveelheid, dan wel door de geringe kwaliteit niet voor ontginning in aanmerking.

De groote waarde van den in Midden-Sumatra begraven kolenrijkdom, reeds zoo vaak van verschillende zijden aangetoond, wordt dan ook door niemand betwist, evenmin als de noodzakelijkheid, om die kolen aan den dag te brengen.

Ik wensch mij dan ook te onthouden van nadere aanprijzing eener kolenontginning en niet opnieuw te betoogen dat de Ombilienkolen in verscheidene Oost-Aziatische havens met de Engelsche en Australische steenkolen kunnen concurreeren, maar wil meer bepaald trachten antwoord te geven op de vraag: ${ }_{n}$ moeten de "Ombilienkolen naar de Westkust, dan wel naar de Oostkust "worden afgevoerd?"

Het Ombilien-kolenveld heeft - hoewel slechts sinds ongeveer acht jaar geleden voor het eerst besproken - een geschiedenis, tot heden alleen in verschillende geschriften geopenbaard.

Het wordt daarom niet ondienstig geacht de verschillende voorstellen tot ontginning en afvoer, hier in enkele regels in herin. nering to brengen.

Den mijningenieur de Greve, die het eerste de Regeering op 
den grooten kolenrijkdom wees, komt de eer toe, ook de eerste te zijn geweest, die een plan tot afvoer aan de hand deed.

Hij stelde den kolenafvoer op den voorgrond, maar wenschteen terecht - den transportweg tevens dienstbaar te maken aan de ontwikkeling der Padangsche Bovenlanden. De Greve acht daartoe in de eerste plaats noodig een spoorweg naar de Westkust. Die weg zou, volgens zijn ontwerp, te Soengeï Doerian (kolenveld) beginnen en van daar door de Lasi-vallei naar Solok en verder over het Barisan-gebergte naar Padang zijn gericht. Hij raamde de kosten van dien weg (105 kilometer) op $f 4,000.000$, het rollend materieel daaronder begrepen.

Hij verlangde daarenboven een secundair spoorwegnet in de Bovenlanden, dat op het kolenstation aan de stamlijn aansluitende over Fort van der Capellen naar Tabeh Patah zou worden gericht en daar gesplitst in twee takken, nl. één over Basso naar Fort de Kock, één andere over Piladang naar Pajakombo en Soelikie. Dit secundair net van 138 K. M. zou worden voltooid door een verbinding van Solok met Singkarah, lang $15 \mathrm{~K}$. M.

Doordrongen van het groote gewicht zijner ontdekking roor de ontwikkeling der stoomvaart en van den handel in den Indischen Archipel en innig overtuigd van de groote gevolgen van de ontginning der steenkolenbedding voor de schoone landstreek, welke hij bewoonde, trachtte hij - met ruimen blik het geheel overziende - een algemeen stelsel van afvoer te scheppen, voldoende aan alle behoeften van het heden en de toekomst.

Hij achtte daarom, ter tegemoetkoming aan alle eischen van een verbeterd transportstelsel en ter verzekering van den afvoer der steenkolen, nog een verbinding van het kolenveld met de Oostkust van Sumatra noodig.

Hij vestigde daartoe het oog op de Indragirie, welke hij tot Doerian Gedang bevaarbaar achtte; in zijn stelsel moest dit punt door een spoorweg van 39 kilometer met het kolenstation Soengeï Doerian worden verbonden.

Het is bekend, dat de Greve het leven verloor, op een tocht in het belang van den afvoer oostwaarst ondernomen.

De gunstige berichten van den ingenieur de Greve hebben aanleiding gegeven tot een - meermalen in dit Tijdschrift besproken - aanvraag om concessie tot ontginning van het kolenveld en den aanleg van een spoorweg naar de Westkust.

De Regeering achtte daarentegen een nader terrein-onderzoek van harentwege noodig. 
Aan mij viel de vereerende onderscheiding te beurt met dit onderzoek te worden belast.

De opdracht was: "een onderzoek in te stellen naar de beste "gelegenheid, om op Sumatra spoorwegen aan te leggen, zoo "ter verbetering van het transportstelsel in het Gouvernement ${ }_{n}$ Sumatra's Westkust in het algemeen, als in het bijzonder voor "den afvoer van steenkolen uit de Padangsche Bovenlanden naar „de kusten."

Na aankomst op Sumatra werd in de eerste plaats een onderzoek ingesteld naar de verbinding van het kolenveld met de Westkust. De uitkomsten van dezen arbeid zijn door het Departement van Koloniën gepubliceerd.

Volledigheidshalve zij vermeld, dat dit onderzoek aanleiding gaf, om voor te stellen den aanleg van een staatsspoorweg van het Kolenveld naar de Brandewijnsbaai met een zijtak naar Padang, en voorts de exploitatie van dien weg en de ontginning der steenkolenmijn van staatswege.

Het voor ontginning benoodigd kapitaal werd op $f 500.000$ gesteld, en voor de haven - en daarmede in verband staande werken $-f 2,600.000$ noodig geacht, terwijl de anlegkosten van den spoorweg en het voor de exploitatie benoodigd rollend materieel op $f 22,500.000$ zijn geraamd.

Van het voor deze werken te besteden kapitaal werd, bij een jaarlijksch debiet van 100.000 ton steenkolen, $3.75 \mathrm{pCt}$. rente verwacht, terwijl de winst bij tweevoudig gebruik tot $6.3 \mathrm{pCt}$. zal stijgen.

Jhr. Mr. J. K. W. Quarles van Ufford achtte het Rapport de eer eener bespreking in dit tijdschrift waard. $\left({ }^{*}\right)$

$\left(^{*}\right)$ Zie Eeonomist 1877 bladz. 620 en v. Erkentelijk voor die anksondiging, vermenn ik toch te mogen opmerken, dat - met het oog op de mij verstrekte opdracht - mijn arbeid juister kon beoordeeld zijn, dan van het standpunt van den concessie-aanvrager.

De omstandigheden eischten een uitvoerig rapport.

Uit den aard der zaak moesten verscheidene technische kwesties in het "rapport" worden behandeld. Wat toch was 't geval?

In een topographiseh nagenoeg onbekende landstreek moest de beste richting worden bepaald van een spoorweg, waarvan slechts één uiteinde (het Kolenveld) en dañ nog slechts zeer globaal was aangegeven, terwijl omtrent het op dien spoorweg te verwachten verkeer geen gegevens voorhanden waren. Daarom wareu in de eerste plaats bet terrein en de kust te bestudeeren en gegevens te verzameleu omtrent de bevolking en productie van de landstreek, omtrent de baudels. 
In een tweede - nog niet gepubliceerd, maar thans voor rekening van het Departement van Koloniën ter perse gelegd rapport werd spoorwegaanleg in de Padangsche Bovenlanden behandeld en tevens onderzocht, welke rivieren voor afvoer oostwaarts in aanmerking komen (*).

beweging en het vermoedelijk kolendebiet enz. Benmanl in het bezit dier gegevens kon tot het eigenlijk ontwerpen van den spoorweg worden overgegaan.

Gewoonlijk wordt den ingenienr eeu programma gegeven, waaraan zijn ontwerp moet voldoen. Dit programma kon mij - bij gemis der noodige topographisehe, hydrographische, commercieele en econonomische gegevens - niet ter band worden gesteld. Ik moest me dus zelf een programma verschaffen, dat de hoofdbeginselen bevatte, warop het ontwerp zon berusten, met andere woorden: ik moest vooraf het karakter van den te ontwerpen spoorweg omsehrijveu. Onder dezen zeer omvuttenden arbeid kan men begrijpen: het vaststelles der te bezigen spoorwijdte, de toe te laten hellingen, de minimum kromtestraal der gebogen gedeelten, in één woord al wat betrekking heeft op de elementen van het ontwerp of in verband staat met de technische exploitatie van den weg.

Het zou anmatigend geweest zijn mijn programma te vermelden in enkele woorden, zonder toelichting. Jegens de Regeering was ik verplicht rekenschap te geven van de gronden, waarop dat programma berust.

Referent vermeent, dat ik bij mijn arbeid "wel wat veel heb omgehaald " en weet ndat het lijvig stnk heel wat in omvaug verschilt met het blad papier, "waarop praktische engelsche ingenieurs gewoon zijn hune berekeningen ten op"zichte van een of ander tot stand te brengeu, publiek werk ter neer te schrijveu." Terwijl referent vernam wdat er meer geleerdheid in voorkomt, dan eigenlijk "noodig was," wordt mij zelfs "vertoon van geleerdheid * verweten.

De heer $Q$. wist of vernam waarschijnlijk niet, dat engelsche ingenieurs vier jaar hebbeu besteed aan de opname ten behoeve van den overgang van den Bhore Ghant (24 kilometer) eu, dat aan de kenze der meter-spoorwijdte voor het tweede in Britsch-Indiê aan te leggeu spoorweguet een nitgebreide enquête is voorafgegaan, waarvau vellon druks getuigen. Ook in Europa arbeidt men minder vlug (oppervlakkig?) dau referent vermoedt. Ik moet mij kortheidshalve het genoegen ontzeggen dit door voorbeelden te staven; slechts wordt bier herinnerd aan 't door de Oostenrijksche Regeering gepubliceerde "Technischer Bericht" over den ontworpen Arlberger spoorweg en aan de uitgebreide technisehe literatuur in zake de Gotthardbaan o, a. aan de uitvoerige rapporten van den hoofdingenieur W. Hellwag.

Dindelijk zij medegedeeld, dat het Rapport reeds vóór mijn teraykomst in het vaderland was gedrukt; het drukken der kaart heeft de uitgave enkele maanden vertraagd. (Vergelijk Economist 1877 bldz. 626 noot).

(*) Aan den schrijver der Koloniale Kroniek (Vergelijk Economist 1878 bldz. 256) kan ik mededeelen, dat ik mij ernstig met den kolenafvoer naar de Oostkust heb bezig gehouden en dat zelfs indertijd een plan de campagne voor een techuisch oudercoek der Indragirie is opgenaakt.

De redenen, waarom dit onderzoek niet in loco is ingesteld, werden o, a. 
Mijn aandacht bleef - ook na het eindigen mijner taak - op de hier ter sprake gebrachte kwestie gevestigd.

Nogmaals werd do mogelijkheid overwogen, om den kolenafvoer te verzekeren langs een naar het Westerstrand gerichten - doch minder kostbaren - spoorweg, dan het eerste ontwerp gaf. Ik had daarbij op het oog toepassing van een der nieuwere uityindingen op het gebied der spoorweg-techniek, waarvan in 1874 (en zelfs in 1875) de deugdelijkheid nog niet door de praktijk was aangetoond $\left({ }^{*}\right)$.

Ik kan hier - zonder onbescheiden te zijn - mededeelen, dat het daartoe ingesteld onderzoek gunstige uitkomsten heeft gegeven ( $\dagger$ ).

Het oorspronkelijk ontwerp moet $\mathrm{nl}$. worden vervangen door een spoorweg, welke van de Brandewijnsbaai langs Padang door de zoogenaamde Kloof naar Padang-Pandjang is gericht en verder dalende naar het meer van Singkarah over Solok het Kolenveld bereikt. In de Kloof der Aneh is een stangenbaan (systeem Riggenbach) noodig.

Deze richting (lang 149 kilometer) vermijdt groote terreinbezwaren en daarmede de vele tunnels en viaducten, welke het eerste ontwerp vereischte.

De weg zal, volgens nauwkeurige raming, een uitgaaf van $f 15,500.000$ of met inbegrip van het rollend materieel van $f 16,800.000$ vorderen, en kan in zeven jaar gereed zijn.

De gewijzigde richting geeft tegenover het eerste ontwerp

vermeld in het Koloniagl Verslag voor 1875 (t. a. pl. bldz, 135). De oudervinding der laatste maanden heeft overtuigend bewezen, dat een grondig techniselı onderzoek van het onaf hankelijk stroomgebied der Indragiric in 1976 onmogelijk was.

Reeda bij aanvang van leu arbeid had ik de overtuiging, dat afvoer naar de Westkust hoofdzaak is, en dat gemeenschap met de Oostkust slechts in de tweede plats in anmerking komt; sinds be॥ ik in die overtuiging gesterkt.

Steeds is geheel overeenkomstig dit beginsel gehandeld. $\mathrm{Er}$ bestaat dan ouk slechts schijubaar verschil tussehen dit begiusel en den inboud van miju tweede halfjaarlijksch verslag (Zie Economist 1877 bldz, 624 noot). Slechts door eenvoudige verkenning is onderzoeht of het voor te stellen tracé : voor zooveel bet gedeelte van bet kolenveld tot de Lasi betreft, ook voor een eventueel te bonwen spoorweg door het dal der Indragirie kan dienen, terwijl bij de plaatsbepaling van het station Sawah-Lawas (Solok) op de aansluiting van een spoorweg door de Bovenlanden werd gelet.

(*) Zie: Kolouiaal Verslag 1877 bldz. 149.

( $\dagger$ ) De uitkumsteu vau dit nader ouderzoek ziju neergelegd in een. Rapport, r'at weldra loor het Departement van Koloniën zal worden nitgegeven.

LCON. 1878. 
$f 5,700.000$ besparing, heeft niettegenstaande de grooter lengte, bij gelijke kolenprijzen, iets grooter rentabiliteit en komt eindelijk tegemoet aan het verkeer van een belangrijk deel der Bovenlanden.

Intusschen vatte het Aardrijkskundig Genootschap het voornemen op, een wetenschappelijke expeditie naar Centraal-Sumatra te zenden.

Het was voorzeker een gelukkige gedachte der jeugdige Vereeniging, om hare eerste krachten te wijden aan een der schoonste eilanden van den Archipel.

Haar roepstem om materieële hulp werd alom in den lande met welgevallen vernomen, terwijl de ontvangen giften - hoewel nog niet zoo talrijk en aanzienlijk, als men zou wenschen - getuigen, dat het ontwikkelde publiek de pogingen van het Genootschap op prijs stelt. Nog meer verblijdde zeker ieder belangstellende de tijding, dat verscheidene wakkere en kundige Nederlanders wenschten onder de tochtgenooten behooren.

De expeditie zou in de eerste plaats strekken, om de groote leemten in onze aardrijkskundige kennis weg te nemen, maar tevens op natuur-historisch gebied werkzaam zijn en de hulpbronnen van het groote eiland bestudeeren.

Langzamerhand werd op den voorgrond gesteld, dat de expeditie nuttig werkzaam kon zijn, om de mogelijkheid van afvoer der Ombilienkolen langs de Djambi te onderzoeken en tevens voor cultuur geschikte terreinen op te sporen.

Evenwel bestaat aan vruchtbare terreinen binnen ons gebied geen gebrek. Op de oostelijke helling van het Barisan-gebergte wachten verscheidene duizendtallen bouws woeste, met maagdelijk bosch bedekte gronden op Europeesch kapitaal, op Nederlandschen ondernemingsgeest. Die terreinen, te midden eener goed bevolkte landstreek, zijn uitstekend geschikt voor de teelt van koffie, kaneel en andere producten voor de Europeesche markt. Enkele bestaande ontginningen bewijzen het welbegrepen eigenbelang der bezitters, die, met een dikke humuslagg bedekte, berghellingen in een rentegevende landbouw-onderneming herschapen hebben.

De gronden, welke de expeditie van het Aardrijkskundtg Genootschap vermeent te kunnen aanwijzen, liggen daarentegen in een betrekkelijk lage en nagenoeg onbewoonde landstreek.

Evenmin als men op de oostelijke grenzen van het Gouvernement Sumatra's Westkust woeste gronden behoeft te zoeken, zal een 
onderzoek naar steenkolenafvoer oostwaarts aan het doel beantwoorden $\left({ }^{*}\right)$.

De expeditie van het Aardrijkskundig genootschap heeft weder op nieuw de aandacht op de Ombilienkolen gevestigd en velen de overtriging geschonken, dat afvoer langs de Djambi niet alleen mogelijk is, maar zelfs wenschelijker dan afvoer naar de Westkust (Padang-Brandewijnsbaai).

De voorstanders van afvoer oostwaarts hebben zich, bij beoordeeling dier kwestie, niet altijd rekenschap gegeven van den verbruikskring der Ombilien-kolen; hieronder verstaande den omtrek, waarbinnen die kolen met andere even goede kolensoorten kunnen mededingen.

Het is uiterst moeielijk dien omtrek te bepalen voor een handelsartikel, waarvan de prijzen voortdurend afwisselen en van zoovele nevenomstandigheden af hangen.

De Ombilienkolen staan in hoedanigheid naast, zoo niet boven, de beste Engelsche stoomkolen en kunnen, zooals elders werd aangetoond, met voordeel worden vervoerd naar de verschillende havens in den Indischen archipel, hoogstwaarschijnlijk naar Singapore en Point de Galle en wellicht ook naar Hongkong ( $\dagger$ ).

In 1872 - dus in geheel normale omstandigheden - werden in den Indischen Archipel ongeveer 103.000 ton steenkolen verbruikt; waarvan:



terwijl bovendien in de drie eerstgenoemde havens nog 20000 ton voor verschillende niet bij name bekende, verbruikers noodig waren.

(*) Ik wensch hier al dadelijk op te merken, dat het Aardrijkskundig Geuootschap en zijn streven mijue volle sympathie heef; nitt bet minst geldt die sympathie de mannen, die in gindsclie gewcsteu te middeu van vele outberingen werkzaam ziju in het belang der wetenschap. I $k$ volg hen met warme belangstelling, en zal hun groote verdiensten in geen enkel opzicht verkleives. Ik vermeen, dat men het gewicht hunner onderzoekingen niet moet afmeten naar het direct materieel voordeal, dat ze kunoen opleveren, maar naar haar wetenschappelijke waarde, welke imıer, zij 't dan ook langs indirekten weg, aan haudel eu nijverlieid ten goede komen.

$(\dagger)$ Voor uadere bijzonderheden wordt verwezen naar mijn "Rapport over den "aauleg van cen spoorweg ter verbiudiug vau de Onbilien-koleuvelden op, Sunatra" onet de Indische Zee" en meer bejaald hoofdstnk VI $\{2$. 
Sinds 1872 is - zelfs afgezien van de vermeerdering der Marine en van tijdelijke stoomvaartlijnen - de geregelde stoomvaart belangrijk uitgebreid. Men denke daarbij in de eerste plaats aan de nieuwe lijnen door de Nederlandsch-Indische stoomvaartmaatschappij in het leven geroepen, de thans geregelde stoomvaart op Australie en verder aan de particuliere stoomschepen in het oostelijk deel van den Archipel.

Bovendien is sinds 1872 het stoombootverkeer tusschen Nederland en Java belangrijk toegenomen, terwijl men ook niet mag vergeten, dat Java over eenige jaren een spoorwegnet van 1100 ì 1200 kilometers zal bezitten, waarvoor zeker 30000 ton steenkolen 's jaars noodig zijn.

Men kan dus veilig - naar aanleiding van een en ander - het jaarlijksch steenkolenverbruik in den Archipel over eenige jaren op 150.000 ton stellen, welke voornamelijk in Batavia, Samarang, Soerabaja, Tjilatjap en Padang noodig zijn, terwijl wellicht later een kolenstation nabij Sumatra's noordelijk uiteinde wenschelijk is $\left({ }^{*}\right)$.

Bovengenoemde 20.000 ton over de drie eerstgenoemde havens erdeelende, wordt het jaarlijksch steenkolenverbruik over eenige jaren gesteld als rolgt:

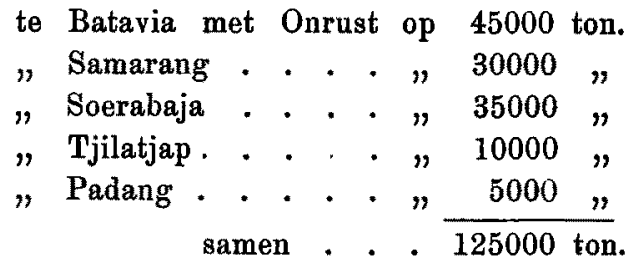

Men mag met grond verwachten, dat in de behoefte aan deze 125000 ton, even als in die $\operatorname{aan} 251100$ ton elders in den Archipel, door Ombilien-kolen zal worden voorzien.

In 1873 werden bovendien in andere voorname havens van Zuidoostelijk Azië de volgende hoeveelheden Engelsche kolen aangevoerd:

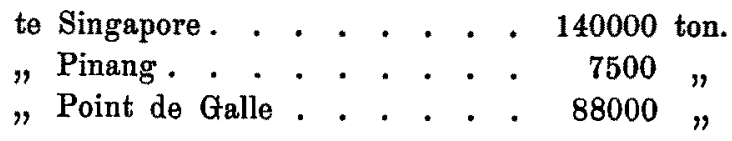

(*) In 1872 werdeu voor rekening van het Departement van Marine 253 tou naar Tjilatją gebracht. Later zullen daar te kolen voor de lijnen Tjitjalenka-rjilatjap eu Tjiatjap-Djoetjucarta (samen ongeveer 400 kiloineter) worden aaugevoerd. 


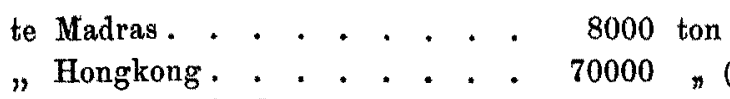

De geringe consumtie doet van Pinang en Madras weinig voor de Ombilien-kolen hopen.

Te Singapore worden hoogstwaarschijnlijk de kolen grootendeels aangevoerd door schepen, die, de brandstof als ballast innemende, uit Engeland naar Oost-Azië, om lading gaan. Het zal dus wol nimmer aan de Ombilien-kolen gelukken, de Engelsehe steenkolen geheel van de markt te dringen; men zal zich gelukkig mogen rekenen, wanneer men er in slaagt de Sumatrakolen een afzet $\operatorname{van} 500 \cdot 30$ ton te verzekeren.

op Ceylon zijn de stoomvaartmaatschappijen, wier lijnen geregeld over Point de Galle gaan, nagenoeg de eenige verbruikers; zij voeren de kolen steeds aan voor eigen rekening. De „Message"ries Maritimes" en de "Pen. and Or. Steam-Nav.-Comy" bezitten zeilschepen, waarmede zij haar kolenvoorraad op Point de Galle aanvullen. Men mag daarom van afvoer der Ombilienkolen naar dit middelpunt van het stoomvaart-verkeer welslagen verwachten.

Omtrent het vermoedelijk debiet van Sumatra-kolen te Hongkong kan men weinig voorspellen. Het handelsverkeer tussehen den Archipel en China is betrekkelijk onbeduidend, terwijl aan de andere zijde de Australische kolen, welke bij de Ombilien-kolen verre ten achter staan en grooter afstand moeten afleggen, te Hongkong gereeden aftrek vinden.

Ik vermeen, zonder de verwachting te hoog te spannen, te mogen aannemen, dat het verbruik aan Ombilien-kolen - na eenige jaren als het product voldoende bekendheid zal hebben erlangd - zal bedragen:

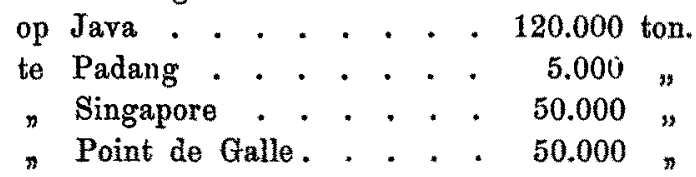

Men zal voorzeker zeer tevreden mogen zijn, wanneer deze uitkomst eenmaal is bereikt. ( $\dagger$

(*) Bopendien werden te Singapore 9500 ton Australische en te Hongkong 76000 ton Australische en andere kolen aangevoerd.

( $\dagger$ De Heer Quarles schrijft: "Aan de Oostkust moeten wij da kolen hobben, "willen wij er gamakkelijk een ruim debiet van verkrijgen. Op den prijs, waar"yoor men ann de Oostkust de kolen kau leverea, daarop komt het aan. Moeten "zij eerst naxr de Westknst, en van daar uaar de Oostkust, dit ual den prijs "dè̀ì aanzienlijk verhoogen," (Economist 1878 bldz. 257.) 
Kunnen en moeten deze kolen naar de Brandewijnsbaai dan wel naar de Oostkust worden vervoerd?

Afvoer naar de Westkust (Brandewijnsbaai) is mogelijk; geen enkel technisch bezwaar verzet zich tegen den aanleg of de exploitatie van een derwaarts gerichten spoorweg, terwijl de in de baai ontworpen haven door trans-atlantische steamers met 7 meter en kolenschepen met 6 meter diepgang kan worden gebruikt.

Daarentegen kan de vraag: „is afvoer oostwaarts mogelijk?" niet aanstonds worden beantwoord.

De tegenwoordige politieke gezindheid der nog onafhankelijke staatjes van centraal-Sumatra stelt aan afvoer oostwaarts geen onoverkomelijk beletsel in den weg, maar kan dien hoogstens eenige jaren vertragen. Men mag met grond vertrouwen, dat - wanneer men slechts in een welwillende afwachtende houding blijft volharden - het binnen kirter of langer tijd aan het beleid der Indische Regeering zal gelukken, om het Nederlandsch gezag in Centraal-Sumatra te doen erkennen.

Vier groote rivieren met haar bronnen in de Padangsche Bovenlanden, stroomen naar het Oosterstrand, nl. de Siak, de Kampar, de Indragirie en de Djambi.

Het wordt overbodig geacht hier an te toonen, dat beide eerstgenoemde nimmer aan het beoogde doel kunnen dienstbaar zijn.

De Indragirie met een uitgestrekt stroomgebied schijnt daarentegen door de natuur aangewezen als de weg, waarlangs de steenkolen de zee moeten bereiken $(*)$.

Deze meening, waarvoor geen enkele grond wordt angevoerd, is blijkens de medegedeelde cijfers minder jnist. Men zal toch wel niet vermeenen, dat de in vaste lijnen varende steamers hun koers nasr de Oostkust zullen richten, om dààr hun bunkers te vullen.

Bij afroer naar de Westkust zullen de Nederlandsche stoomschepen en enkele vaartuigen der Ned. Ind. Stoomvaartmaats. te Padang kolen innemen; die hoeveelheid zal evenwel niet aanzienlijk zijn. Hetzij het vervoer naar de West- dan wel naar de Oostknat wordt gericht, steeds moet de groote massa der an den dag te brengen kolen met transportschepen naar bovengenoemde havens worden gebracht.

$\left({ }^{*}\right)$ Ik kan den Heer D. D. Veth niet toegeven, dat de waterstand in de Batang Hari minder afhankelijk is van den droogen of natten moeson dan die der Indragirie en dat dns eerstgenoemde rivier veel gunstiger is voor een geregelde sleepvaart. (Zie "Berichten Snmatra-expeditie" no. 3 bldz. 73.)

Het stroomgebied der Boven-Kwantan strekt zich uit van den Boekiet Gedang, of van $5^{\prime}$ benoorden den evenaar, tot $1^{\circ} 5^{\prime}$ zuiderbreudte en westwarts tot de kruin van hol Barisan-gebergte. Het is vrij wel met bosch bedekt, omvat landstrukin mati aser rurschillende noterevlogische toestanden en heeft dientengerulge 
De Ombilien, de machtige bovenrivier der Indragirie, splitst het kolenveld in twee deelen; het ligt dus voor de hand, om de kolen aanstonds in riviervaartuigen te laden en ze daarmede aan de zeeschepen toe te voeren.

De natuur verzet zich evenwel hiertegen; het bed der Ombilien en meer benedenwaarts van de Kwantan - is met rotsblokken bezaaid; ondiepten en stroomversnellingen maken de boveurivier onbevaarbaar.

Men moet daarom de steenkolen per spoorweg vervoeren naar het punt, tot waar de rivier ten allen tijde voor riviervaartuigen van behoorlijk laadvermogen bevaarbaar is.

Men verkeert evenwel omtrent den toestand der rivier en hare monden in de grootste onzekerheid.

Volgens verkregen inlichtingen is de Indragirie ten allen tijde tot Loeboe Ambatjang, ongeveer 130 Eng. zeemijlen van den mond, bevaarbaar voor zeeprauwen van 5 kojang en bij middelbaren waterstand zelfs voor prauwen van 10 kojang.

In de laatste jaren zouden enkele Chineesche jonken tot Tjarantie zijn opgekomen; zelfs moet in den aanvang van 1875 een dier vaartuigen voor Si Mandalah zijn geweest.

De juistheid dezer inlichtingen, welke wijlen controleur. Baron von Hoëvell van inlanders ontving, is slechts ter plaatse te constateeren.

Men moet voorloopig aannemen, dat de scheepvaart bij Loeboe Ambatjang zal beginnen, wat een spoorwegverbinding van dit punt met het kolenveld eischt.

Deze spoorweg, minstens lang 90 kilometers, maar hoogstwaarschijnlijk langer, zou nog op Nederlandsch grondgebied zeer kostbare werken eischen.

Omtrent den toestand der benedenrivier en hare monden zijn slechts zeer tegenstrijdige berichten voorhanden. Men weet slechts met zekerheid, dat de Indragirie, als alle oostwaarts stroomende rivieren, een delta vormt, en dat zij in het benedengedeelte stroomt door een laag land, dat bij hooge vloeden onder water komt.

De mijningenieur de Greve vermeende uit ingewonnen berichten te mogen besluiten, dat de Indragirie aan hare monding alle ge-

een grooten minimum-afvoer. De ligging nabij dell evenaar maakt de Indrigarie minder af hankelijk ran den invloed der moesons dan de Zuidelijker gelegen Djasabi, terwijl men bovendien niet ung vergeten, dat het meer van Singkarah, als regelingsbassiu, belangrijke diensten bewijst. 
schiktheid bezit voor het binnenloopen van groote schepen, en dat zij tot hoog stroomopwaarts voor schepen van minder diepgang, ja tot boven Ringat, voor kofschepen beraarbaar is.

De heer E. Netscher, lid van den Raad van N.-I., die als resident van Riouw de Indragirie bezocht, weet daarentegen uit aanschouwing, dat de mondingen bestaan uit zachte modder met ver in zee uitstekende banken.

Zoolang nadere onderzoekingen de onjuistheid van dit laatste bericht niet aantoonen, moet men de Indragirie ongeschikt verklaren voor afvoer der steenkolen. (*)

Er bestaat evenwel gegronde vrees dat - al leeren latere opnemingen, dat de kolentransportschepen ten allen tijde de Indragirie kunnen binnenloopen - afvoer langs die rivier niet raadzaam is, met het $00 \mathrm{~g}$ op de groote kosten van den verbindingsspoorweg, te meer daar die transportweg door een nagenoeg onbewoond land voert.

In den laatsten tijd is de Djambi genoemd, als de aangewezen weg tot steenkolenafvoer oostwaarts.

Ik wil gaarne bekennen, dat ik die rivier vroeger nooit uit dat oogpunt heb beschouwd.

De Djambi is dan ook eerst ernstig als afvoerweg ter sprake gebracht, nadat de HH. van Hasselt en Veth hadden ontdekt, dat de Batang Hari de grenzen van het Nederlandsch gebied veel noordelijker nadert dan men wel vermoedde.

Deze leden der expeditie mogen - behalve op hun overigen arbeid op geographisch gebied - terecht trotsch zijn op deze ontdekking, welke topographisch groote beteekenis heeft.

Die beteekenis wordt evenwel door velen overschat, wanneer zij vermeenen daardoor aan de Djambi de geschiktheid tot afvoer der Ombilien-kolen te kunnen toekennen.

Wat toch is het geval?

De kolenvelden liggen in het gebied der Indragirie en moeten

(*) Het Etst-Major van Z. M. stoomschip Coehoorn, kommandant wijlen den Luit. $t / Z$ le klasse Engelvaart, onderzocht in den aanvang van 1873 de monden der Indragirie.

Enkele takken waren over een gezamenlijke lengte van 45 kilometers opgenomen, toen geuoemde oorlogsbodem oaar Noord-Sumatra moest vertrekken.

De Luitenaut $t / Z$. Engelvaurt stierf op Atjeh's strand, alvorens omtrent zijn arbeid nadere inlichtingen te kunnen geven.

Raadpleging der door bem vervaardigde kaart gaf geen gunstigen indruk omirent de bevaarbaarheid der rivierarmen. 
dus door een spoorweg vereenigd worden met de Djambi ter plaatse, waar ze voor kleine kolenvaartuigen bevaarbaar is.

Volgens den heer D. D. Veth moet de spoorweg het Kolenveld met $\mathrm{Si}$ Goentoer of liever met het meer benedenwaarts gelegen Si Tioen rerbinden (*).

De kolen worden daar aan het verkeer te water overgegeven, om de Batang Hari of Djambi af te zakken tot het punt, waar de riviervaart voor het zeeverkeer moet plaats maken.

Het is wenschelijk te onderzoeken of dit mogelijk is.

Men dient zich daartoe vooraf rekenschap te geven van de wijze, waarop het kolenvervoer zal geschieden.

Het is van voldoende bekendheid, dat de kolentransportschepen de Djambi niet kunnen opvaren tot den spoorweg-terminus, maar dat de binnenlandsohe waterweg als verbinding tusschen den spoorweg en de zee moet dienen.

De tot eenige stoomvaartlijn behoorende schepen zullen nimmer de Djambi-monden naderen, om kolen in te nemen, omdat geen

(*) Zie: Berichten Sumatra-expeditie no. 3, bla., 71 en $v$, Zonder dea Heer Veth in al zijn beschonwingen te volgen, te meer daar de verdienstelijke onderzoeker, door afwezigheid, geen repliek kan leveren, zij hier slechts gewezen op de onjuistheid van het op bldz. 72 an Europa ter vergelijking ontleend voorbeeld.

De Heer V. schrijft o. a. in hoofdzaak, nonderstel aan den bovenloop van den "Riju uitgestrekte kolenbeddingen. waarvan de kolen naar zee moeten vervoerd "worden; niemand zal dan op het denkbeeld komen, om een spoorweg naar "Venetie of Genus te bouwen, maar het allereerst zon zeker het denkbeeld go"opperd worden een spoorweg te maken naar het punt van den Rijn, waar "vervoer te water mogelijk wordt. Denkt men zich nu ten noorden der Alpen "een andere rivier, door lage waterscheidingen van de kolenbeddingen gescheiden, "maar voor de scheepvaart vroeger en beter geschikt dan de Rijn, dan kan men "zich een roorstelling maken van den toestand op Sumatra enz."

En wat geschiedt?

De Gotthard-baan, zoowel in aanleg als later in exploitatie een der kostbaarste spoorwegen van Europa, zal volgens de ontwerpers o. a. moeten dienen, om in Noord-Italie concurrentie van de Saar- en Ruhrkolen met de Engelsche kolen mogelijk te maken. Men moge deze meening niet deelen, zooveel is zeker, dat de Spoorwegmaatschappijen, welke dit vervoer voornamelijk ten goede zou komen (de Pruiss- en Bad. Staatssp., de Elssass.--Loth.-Rijksb., de Berg-Märk-, Rheinisehe-, Cöln.-Mindener-, Hess-Ladw. en Pfälz-banen) volgens de Berner conferentie (Overeenk. dd. 15 Och. 1869 en 28 Oct. 1871) ongeveer 12 millioen 'francs bijdragen. Zij schijnen 't dus mogelijk te achtex, om over een langen en gedeeltelijk moeielijken spoorweg te concurreeren met de Engelsche kolen, welke uit uitstekend gelegen on van alle hulpmiddelen voorziene havens, in groote zeeschepen worden aangevoerd. 
handelsbelangen daar ooit hunne tegenwoordigheid zullen eischen. $\mathrm{Zij}$ zullen in een der Aziatische havens hun kolen-voorraad aanvullen; daarheen moeten dus de Ombilien-kolen in weinig diepgaande steamers of met zeilschepen worden gebracht. In mogelijke directe vraag naar kolen door de groote schepen kan dan door oprichting van een drijvend depot nabij den mond worden voorzien.

Het komt daarom in overweging het beneden-établissement zoo hoog op de rivier te plaatsen, dat slechts vaartuigen van beperkten diepgang tot daar kunnen opstoomen.

De kolen worden dus op de ontginningsplaats in de waggons gestort, te $\mathrm{Si}$ Tioen in de rivier-vaartuigen geladen en eindelijk nabij den riviermond aan de zeeschepen overgegeven $\left({ }^{*}\right)$.

De Djambi vormt een delta met zes takken. In het ondiepste gedeelte van de geul vòòr den mond van den roornaamsten tak, de Nioer, staat bij laagsten waterstand 5 , bij hoogsten 18 voet. De bedding bestaat uit vasten grond $(\dagger)$.

Volgens andere inlichtingen staat in de geul van die bank, bij lage standen nog 2.15 meter water en bedraagt het verval bij doode getijden ongeveer 1,80 meter, bij springtijden ongeveer 3 meter.

Schepen van ongeveer 40 decimeter diepgang kunnen dus hoog water afwachtende - dagelijks binnenkomen, terwijl grooter vaartuigen sleehts bij springtijden kunnen binnenloopen.

De vloed is bij lage rivierstanden nog halverwege Moeära Kompeh (40 Eng. mijl de rivier op) en Djambi te bespeuren, maar bij aanzienlijken afvoer van rivierwater boven Moeära Kompeh niet meer merkbaar (§).

De vloed- en eb-stroomen zullen vermoedelijk tot diephouding der Djambi-monden bijdragen, ofschoon hun werking door de lage, vaak overstroomde, oevers zeker verminderd wordt.

Een en ander noopt, om aan te nemen dat de steamcolliers niet hooger dan Moeära Kompeh de rivier zullen opvaren, om kolen te laden, ofschoon het zeer wel mogelijk is, dat meer uit-

(*) Dit tweemeal overladen is niet alleen kostbaar, maar veroorzaakt vergruizing, dus verlies, warom het wellicht aanbeveling verdient om steenkolenwagens met losse onderstellen te bezigen, waarvan de bakken met kranen op weinig diepgaande vaartuigen gesteld on weder met hetzelfde hulpmiddel boven de transportschepen gebracht en dasrin ontladen worden.

( $\dagger$ Zie: Berichten no. 4 bldz. 94 met bijbehoorende kaart.

(6) Zie: Berichten no, 2 bldz. 28 , 
voerige gegevens leeren, dat de riviervaart nog verder benedenwaarts moet worden voortgezet.

De Djambi is reeds vroeger tot Moeära Tabo bevaren; volgens destijds verzamelde gegevens, kan men den afstand van Moeära Tabo tot Djambi op 164 Eng. mijl on van daar tot Moeära Kompeh op 38 Eng. mijl stellen.

Daarentegen kan de afstand van Si Tioen tot Moeära Tabo slechts bij benadering worden bepaald.

De heer Schouw Santvoort vermeende dat: "als het bovenge"deelte der rivier niet meer bochten heeft dan benedenwaarts, de "afstand van de grens tot Moeära Tabo grooter zal zijn dan 164 "Eng. mijl" en kwam door vergelijking van voorhanden gegevens tot een minimum afstand van 176 Eng. mijl (*).

$\mathrm{Nu}$ ligt evenwel, volgens de berichten der HH. Veth en van Hasselt, Si Goentoer nader bij de grens en noordelijker dan Schouw Santvoort kon vermoeden. Men vermeent daarom geen te ongunstige onderstelling te volgen, door den afstand van Si Tioen tot Moeära Tabo op 190 Eng. mijl te stellen.

De lengte van het riviervak, dat de steenkolen moeten afzakken, kan dus bepaald worden als volgt:

van Si Tioen tot Moeära Tabo . . . . . 190 Eng. mijl.

" Moeära Tabo tot Djambi. . . . . . 164 " "

" Djambi tot Moeära Kompeh . . . . . 38 " "

$$
\text { Samen . . } 392 \text { Eng. mijll. }
$$

De kolen moeten dus over bijna 400 Eng. mijl. langs de rivier worden vervoerd.

Al dadelijk rijst de rraag: "is de vaart van Si Tioen tot "Moeära Kompeh ten allen tijde mogelijk met voor kolenafvoer " geschikte vaartuigen"?

De wakkere Schouw Santvoort heeft ons tot gedeeltelijke beantwoording dier vraag in staat gesteld.

Hij bereikte (dd. 13 April 1877), in een baloengkang met slechts $1 \frac{1}{1}$ voet diepgang de Batang Djoedjoean afzakkende, bij Teloek Kajoe Poetieh de Batang Hari (Djambi), waarlangs hij zijn reis vervolgde.

Het gedeelte der Batang Hari, boven genoemde kampong gelegen, is dus nog nimmer door een reiziger bezocht.

De Batang Hari - bij haar vereeniging met de Djoedjoean

(") Zie: "Plan ran een onderzoekingstocht in Midden Sumatra" door J. Schouw Şantvoort t. a. pl. bldz. 27. 
reeds 70 Meter breer - stroomt als een schoone rivier met een $2 \frac{1}{2}$ à 3 mijls vaart in Zuidoostelijke richting. „Enkele malen deed "zich ook hier de aanwezigheid van ondiepten en banken be"speuren. Ook ziet men van tijd tot tijd, doch meer onder den "wal, een boomstronk even buiten het water uitkomen".

De rivier verbreedt zich op enkele plaatsen tot 100 à 150 meter, terwijl de breedte nog lager, nl. bij kampong Mengoepie (beneden Moeära Tabo) van 60 tot 150 meter wisselt, tot de rivier bij Soenkatie Gedang met 200 meter breedte door een vlak, laag terrein stroomt $(*)$.

De Djambi werd in November 1869. door den resident Ophuizen met de Boni tot Doesoen Moeära Tabo opgestoomd, waar men (in den regentijd) bij $70 \mathrm{M}$. breedte een zandig bed zonder steenen op 6 vadem peilde. Men mag daaruit evenwel nog niet tot bevaarbaarheid der geheele rivier ten allen tijde besluiten.

Immers moest S.S. op de reeds breede Djoedjoean met zijn weinig diepgaande baloengkang aanhoudend manoeuvreeren en steeds op zijn hoede zijn voor alle ondiepten en stroomvorsnellingen $(\dagger)$.

De Hr. van Hasselt schrijft, dat de Batang Hari, even voorbij de grens - beneden den mond der Manoen - reeds een statige stroom is, met meer dan $100 \mathrm{M}$. breedte, maar met hier en daar boven water uitstekende groote granietblokken (§).

Dezelfde verschijnselen doen zich op de Ombilien en op de Kwantan voor; ook daar breede statige rivieren, maar voordurend ondiepten en stroomversnellingen.

De Djambi heeft bovendien een zeer veranderlijken waterspiegel. Terwijl het gewoonlijk van September tot Maart hoog water is, en men meestal in laatstgenoemde maand weder lage standen aantreft, was de rivier in April 1877 ter hoofdplaats Djambi zelfs 5.7 meter boven het laagste peil geweest. Het verschil in waterstand in de verschillende jaargetijden kan zelfs 7 meter bedragen (**).

Terwijl de Hr. S.S. de bovenrivier bij betrekkelijk hooge waterstanden afzakte, werd hem later door lage standen het ten uitvoer leggen zijner plannen verhinderd.

In de laatste dagen van Augustus, "was de waterstand meer

(') Zie: Bericht no. 1 bldz, 5 en no. 2 bldz. $24,26$.

(†) Zie; Bericht no. 2 bldz. 23.

(i) Zie: Bericht no. 2 bldz. 28.

$\left({ }^{* *}\right) \mathrm{Zie}$; Berichten no, 2 bldz, 28 en no. 4 bldz, 86. 
${ }_{n}$ dan 1.5 meter lager dan in gewone jaren, en was in vele jaren "zoo niet voorgekomen". Men verwachtte te Djambi niet dat S.S. Doesoen Tengah zon kunnen bereiken, en toch had het watervlak overal een breedte van ten minste 175 à 200 meter behouden. Bij Doesoen Koewab (even boven Dn Tengah) bleek verder opvaren onmogelijk; het midden der rivier, daar breed 350 meter, lag gedeeltelijk droog (*).

Schouw Santvoort schreef dd. 15 November 1877 uit Djambi: ${ }_{n}$ De waterstand is hier in de Djambi nog steeds ongehoord laag, "zoodat men niet veel hooger dan Dn Tengah (op dit oogenblik "zelfs nog niet eens tot daar) komen kan". Hij kon den 21 sten of 22sten dier maand nog geen gunstiger bericht zenden $(\dagger)$.

Terwijl men gewoonlijk reeds in September hoog water heeft, was de rivier in November 1877 nog onbevaarbaar, en dat nog wel op het benedendeel voor een zeer klein vaartuig, n.l. de stoombarkas van ongeveer één meter diepgang.

Eenige maanden vroeger had men daarentegen buitengewoon hooge standen.

De periodieke veranderingen van den waterspiegel vertoonen dus groote onregelmatigheden.

De Djambi heeft bovendien talrijke scherpe bochten en een zeer onregelmatig en veranderlijk stroombed. Dit blijkt niet alleen uit de kaarten bij bericht no. 2 en no. 4 gevoegd, maar nog veel duidelijker uit de op groote schaal vervaardigde schetskaart, behoorende bij het verhaal van S.S.'s bezoek aan de meeren bij Doesoen Tengah.

Op welke wijze moet men nu op een sterk kronkelende rivier met groot verhang en zeer afwisselenden waterspiegel het kolenvervoer inrichten, wanneer de diepgang der vaartuigen minder dan één meter moet bedragen? (\$)

De oplossing van dit geheel technisch vraagstuk moet op een zeer gedetailleerde rivieropname berusten.

Men stuit al dadelijk op bezwaren. De groote afstand (ongeveer 400 Eng. mijl.) eischt vaartuigen met aanzienlijk laadvermogen, door stoomslepers naar beneden gebracht, terwijl men met het

(*) Zie: Berichten no. 4 bldz, 90 en 91.

(†) Zie: Berichten no. 4 bldz. 94 S.S's brief overgenomen in de Nieuwe Rotterd. Courant dd. 23 Jan. 1878.

(\$) Altijd anugenomen, dat ook tusschen Si Tioen ea Teloek Kajoe Poetieh vaartuigen van ougever één meter diepgang bruikbaar zijn, wat nog gaheel ouzeker is. 
oog op de groote stroomsnelheid de ledige kolenaken gaarne en touage zou terugvoeren, wanneer de somtijds groote diepte (men denke aan een stand van 7 meter boven laagwater) zich hier. tegen niet verzette. De veelvuldige korte bochten en de groote stroomsnelheid verbieden in elk geval de samenstelling van lange treinen.

Men vergete daarenboven niet, dat men moet kunnen voorzien in een jaarlijksch vervoer van 200,000 ton kolen over 400 Eng. mijlen, waarvoor een aanzienlijke vloot van rivierschepen en slepers noodig is.

Het behoeft nauwelijks herinnering, dat aan een grondige rivierverbetering (gesteld, dat ze technisch mogelijk is) niet te denken is; zelfs plaatselijke opruiming van rotsen of steenblokken eischt reeds groote uitgaven $(*)$.

Uit deze korte aanteekeningen blijkt voldoende, dat de geschiktheid der Djambi voor een économisch en geregeld vervoer van steenkolen - waarbij van stremming gedurende eenigen tijd, wegens te lagen waterstand geen sprake mag zijn - ernstig moet betwijfeld worden.

Ik vermeen zelfs te mogen beweeren, dat de thans voorhanden gegevens de onderstelling wettigen, dat de Djambi als afvoerweg oostwaarts bezwaarlijk in aanmerking kan komen ( $\dagger$ ).

Maar al blijken bij een nader onderzoek verscheidene der boven aangestipte bezwaren minder overwegend, dan men thans vermoedt, dan nog blijft het - van een finantieel en politiek standpunt wenschelijk, om de Ombilien-kolen niet naar de Oost- maar naar de Westkust te voeren.

Het is niet moeielijk een en ander met cijfers aan te toonen.

Zooals reeds boven werd vermeld, bestaat er geen enkel technisch bezwaar tegen den aanleg van een spoorweg: KolenveldPadang Pandjang-Padang-haven, welke bij 149 kilometers lengte, (met inbegrip van het rollend materieel) $f 16,800,000$ zal kosten.

De door den heer D. D. Veth voorgestelde spoorweg van Sawah Loento (kolenveld) naar Si Tioen, zal een lengte van ongeveer 140 kilometer verkrijgen.

(*) Mon wenscht slechts te herinneren an de Rijnverbetering benedeu Bingen.

$(\dagger)$ Men zal mij wellicht tegenwerpen, dat - volgeus uit Indië ontvangen berichten - de resident van Palembang de Batang Hari met de "Barito" is opgevaren tot boven den mond der Djoedjoeän. Dežy tocht, welke in de periode der hooge rivierstanden werd volvoerd, levert nog geen bewijs voor de bevaarbaarbeid der rivier "ten allen tijde," 
De voorsteller denkt wel wat lichtvaardig over spoorwegaanleg op Sumatra, wanneer hij vermeent, dat den bouw van een spoorweg naar Si Tioen weinig bezwaren zullen in den weg staan.

De Hr. V. omschrijft den door hem gewenschten spoorweg als volgt:

„Van Sawah Loento naar de Batang Pamoeätan en verder door ${ }_{n}$ het dal der Pelankie over de Soekan naar Si Djoendjoeng, om ${ }_{n}$ van daar over een pas van 120 meter het dal der Koelampi ${ }_{n}$ te bereiken, die rivier tot haar bronnen te volgen, daarna nin het dal der Takoeng over te gaan, om eerst de Pangean nen later in het dal der Batang Hari den terminus Si Tioen te nbereiken." $\left({ }^{*}\right)$

Het terrein tusschen Sawah Loento en Si Tioen is mij slechts voor een zeer klein gedeelte, nl. tot nabij Moeära Bodi bekend.

De weg voert door sterk kronkelende dalen, wat de kaart van den Hr. Veth o. a. voor zooveel de Koelampi betreft aantoont. Nauwkeurige opnemingen leeren steeds, dat de weg in dergelijk terrein langer en kostbaarder wordt dan vluchtige verkenning deed vermoeden.

De oostelijk gerichte spoorweg gaat door het bovendal der Koelampi en der Takoeng, vordert behalve kleine bruggen, tweemaal een overgang van de Polankie, voorts van de Soekan en verder verscheidene bruggen over de Koelampi en Takoeng, terwijl de weg leidt door een nagenoeg onbebouwde landstreek. Alle van elders aan te voeren materialen en hulpmiddelen moeten over 400 Eng. mijl langs een betrekkelijk snel stroomende rivier met weinig diepgaande vaartuigen worden opgevoerd.

Men zal mij daarom wel niet van overdrijving beschuldigen,

(*) Zie Bericht no, 3 bldz, 74.

Men kan van het kolenstation de Batang Pamoeätan niet bereiken, op de wijze als door den heer $V$. wordt voorgesteld. Het personeel der spoorwegopname heeft van dit terreingedeelte een nauwkeurige kaart op groote schaal vervaardigd, waarop verschillende richtingen zijn ontworpen. Dit onderzoek heeft geleerd, dat in de kleine vlakte van Sawah Loento belangrijke werken noodig zijo en dat de bergrug tusschen die vlakte en de vallei der Pamoeätan een tunnel eischt. Door een en ander stijgen de bouwkosten der vier eerste kilometer, met het kolenstation (aan elk spoorwegontwerp gemeen) tot ongeveer $f 1,000,000$. Door bijzondere hulpniddelen kan men wel op het annlegkapitaal besparen, maar slechts ten koste van de exploitatie.

Spoorwegaanleg in dit terrein werd uitroerig behandela in het reeds boven aangehaald rapport, o. a, in $\$ 2$ vau Hoofdst uk XIII. 
wanneer ik de bouwkosten van dezen spoorweg op gemiddeld $f 100.000$ per kilometer stel. $\left(^{*}\right)$

De weg lang 140 kilometer zal dus $f 14,000,000$ kosten. Voegt

(*) Onder dit bedrag ziju alle bijkomende onkosten begrepen; o. a. personeel, onderhoud gedurende den aanleg, werkplaatsen, tijdelijke gebouwen evz.

$\mathrm{Bij}_{\mathrm{ij}}$ de schatting is rekening gehonden met de ondervinding verkregen bij het ontwerpen van ongeveer 350 kilometer spoorweg op Sumatra, zoowel in vlak, als min of meer geaccidenteerd, dan wel zwaar bergterrein. $O$. a. bedraggt de raming per kilouneter:

$a$. Van het gedeelte door de liefelijke manr sterk kroukelende Lasi-vallei (den

Heer V. wel bekend) zonder eenig terreinbezwsar ongeveer . . $f \mathbf{7 8 , 0 0 0}$

b. Van een zuivere vlaktelijn met reel bruggen . . . . . . . - 90,000

c. Van een spoorweg in vrij geaccidenteerd terrein, maar zonder

viaducten of tnnnels. . . . . ............. . . 108,000

d. Van een spoorweg in zwaar bergterrein met viaducten, tnnnels

enz. van . . . . . . . . . . . . . . $f 150,000$ tot - 500,000

Wellicht zal men hier tegenover stellen, dat de spoorweg welke Midden-Java met den weg Soerabaja-Passaroesn zal verbinden op $f 81,000$, de weg ran Buitenzorg naar Tjitjalengka op $f \mathbf{1 1 4 , 0 0 0}$ per kilometer zijn geraamd (met inbegrip van het rollend materieel.)

Men mag echter niet vergeten, dat er bezwaarlijk sprake kan ziju van vergelijking tusschen spoorwegen in topograitsch zeer verschillende landstreken, terwijl op Sumatra's Westkust bij hooger arbeidsloonen ook hooger eenheidsprijzen gelden dan op Java.

En toch schijut unen soms te vermeenen, "dat men tot aanleg van een op de *zuiuigste wijze gebouwden spoorweg met $\frac{2}{3}$ of zelfs thet de helft van het door -mij geraamd aanlegkapital kan volstaan."

Dit is een dwaling; aaudachtige leziug van het door het Dep. v. Kol. nitgegeven Rapport zal de overtuigiug schenken, dat de weg zoo zuinig mogelijk is ontworpen, maar dat op den voorgrond is gesteld, dat van besparing op den onder- en bovenboaw van den weg en op de knnstwerken - ten koste der duaraambeid - nimmer sprake mag zijp.

Ongekeerd behoeft men geen vrees te koesteren, dat de raming - bij uitvoering - zal worden overschredeu.

De eeuheidsprijzen zijn met zorg overwogen en nog nimmer ernstig weerlegd.

De tegenwoordige lage stand der ijzermarkt zon natuurlijk gunstigea invloed hebben, maar evenals verlaging der eenheidsprijzen aan beide richtingen in gelijke mate ten goede komen.

Men mag daarenboven niet vergeten, dat de Oosterspoorweg in veel ongunstiger omstandigheden zal verkeeren, dan een weg naar de Westknst.

De omstandigheid, dat men alle werkkrachten van elders moet aanvoeren, dat alle bonwmaterialen, hulpwerktuigen, levensmiddeleu enz. aan de van alle hulpmiddelen ontbloote Djarabi-mouden ontscheept en laama over $400 \mathrm{Eng}$. mijl moeten worlen opgevoerd, doen zelfs vreezen, dat overschrijding der geraande bouwknsten $(f 14,000,000)$ onvermijdelijk is. 
men hierbij nog ongeveer $\int 80,10$ per kilometer voor rollend materieel, dan verkrijgt men een totaal bedrag van ongeveer $f 15,100,000$ tegenover $f 16,800,000$ voor den spoorweg naar de Brandewijnsbaai.

De afvoer langs de Djambi zal, al is de vaart op die rivier ten allen tijde mogelijk, een vrij aanzienlijk aantal transportvaartuigen eischen. Volgens een globale en voor de onderneming zeer gunstige berekening, zal het vlottend materieel voor een jaarlijksch vervoer van ongeveer 100,000 ton ruim $f 1,30$ ?,000 kosten.

De havenwerken aan de Brandewijnsbaai zijn op $f 2,100,000$ geraamd, terwijl bovendien voor gouvernementsgebouwen (entrepôt-, koffie-, zoutpakhuizen enz.) en kustverlichting $f 500,000$ is uitgetrokken.

Maar ook te Moeära Kompeh, of waar elders aan de Djambimonden, de kolen uit de riviervaartuigen in de zeeschepen worden geladen, zijn handelsinrichtingen als: kaden, losplaatsen en eenige gebouwen noodig, terwijl de Djambi-monden bebakening en verlichting eischen. Het is - bij ontstentenis der noodigste gegevens - niet mogelijk, om de kosten dezer werken, zelfs bij benadering, te bepalen. Men zij evenwel indachtig dat hier sprake is van den bouw van handels-inrichtingen in laag gelegen terrein, dat bij elken hoogen vloed onder water komt. $\left({ }^{*}\right)$

Samen roeging der verschillende nitgaven geeft het volgend overzicht der kosten:

\begin{tabular}{|c|c|c|}
\hline \multirow{2}{*}{$\begin{array}{l}\text { OMSEHRIJVING } \\
\text { DER } \\
\text { ONDERDEELEN. }\end{array}$} & \multicolumn{2}{|c|}{ R I C II TIN G. } \\
\hline & $\begin{array}{l}\text { naar de Brandewijns- } \\
\text { baai. }\end{array}$ & vaar de Oostkust. \\
\hline 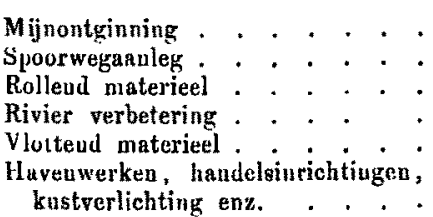 & $\begin{array}{lr}f & 500,000 \\
- & 15,500,000 \\
-\quad 1,300,000\end{array}$ & $\begin{array}{c}f \quad 500,000 \\
-14,000,000 \\
-\quad 1,100,000 \\
\text { Memorie. } \\
1,300,000 \\
\text { Memorie. }\end{array}$ \\
\hline
\end{tabular}

Uit deze cijfers blijkt voldoende, dat zoodra verbetering der rivier ernstig ter sprake komt, de verbinding van het kolenveld met de Oostkust belangrijk meer zal kosten dan de spoorweg naar de Brandewijnsbari.

$\mathrm{Bij}$ de groote onzekerheid omtrent den toestand der rivier en

(*) Zie Bericht no. 4 bldz. 87.

ECON. 1878. 
de wijze, waarop de riviervaart moet worden ingericht, kan men de absolute transportkosten bezwaarlijk schatten en moet daarom met vergelijking der kosten volstaan.

Wat het spoorwegverkeer betreft, zullen de kosten per tonkilometer ongeveer gelijk zijn. De oostwaarts gerichte spoorweg, ofschoon in den eigenlijken zin geen bergspoorweg, oversehrijdt twee waterscheidingen. De spoorweg naar de Brandewijnsbaai is over 92 kilometer een vlaktelijn en heeft slechts over 17,5 kilometer het karakter oener bergbaan, terwijl de exploitatie der stangenbaan door de Kloof der Aneh, met dalwaarts gericht verkeer, niet kostbaar is.

De Oosterspoorweg is ongeveer 9 kilometer korter dan de andere; de geringe lengte zal ongeveer aequivaleeren met de onkosten eener tweede overlading nabij den riviermond. Men kan dus aannemen - deze overlading verder buiten rekening latende - dat de steenkolen te Si Tioen evenveel kosten, als bij aankomst aan de Brandewijnsbaai.

De kosten van het vervoer te water kunnen in hoofdzaak evenredig worden gesteld aan den afstand, ofschoon deze onderstelling voor groote afstanden eenigszins ongunstig is.

Stelt men verder de kosten van het vervoer langs de rivier (over ongeveer 400 mijl) per eenheid van afstand gelijk aan de transportkosten over zee, dan handelt men geheel ten voordeele van afvoer naar de Oostkust.

Ter vergelijking van de kosten van vervoer in beide richtingen naar verschillende havens kan 't volgend overzicht der afstanden dienen.

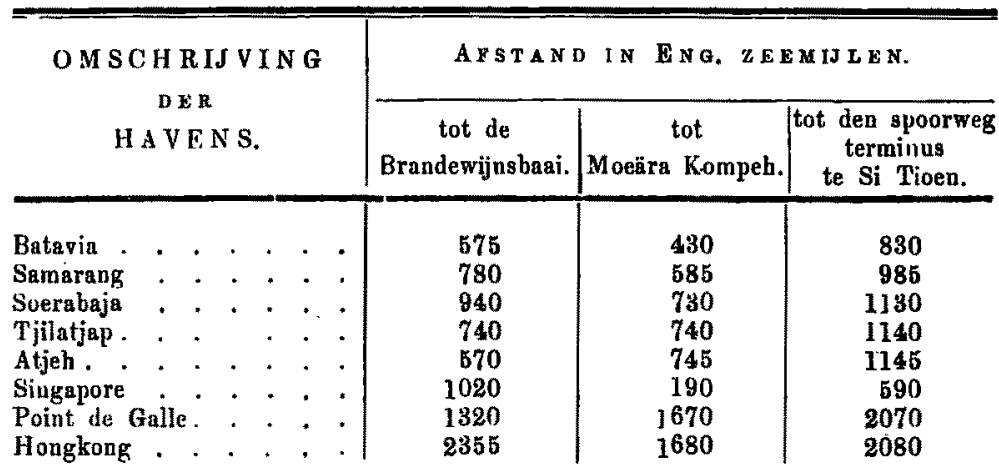

De haven aan de Brandewijnsbaai is dus - voor zooveel het zeeverkeer betreft - gunstiger gelegen dan Moeära Kompeh voor 
het transport naar Atjeh en Point de Galle, terwijl beide havens gelijken afstand hebben tot Tjilatjap.

Brengt men daarenboven het riviertransport in rekening, dan blijkt onmiddellijk, dat afvoer naar de oostkust slechts in aanmerking komt voor de in Singapore en Hongkong te verkoopen steenkolen. Afroer naar het Westerstrand verdient daarentegen verre de voorkeur, voor zooveel he'f verkeer met de havens in den Archipel en Point de Galle betreft.

Elke mijl geringer afstand, geeft besparing op de scheepsvracht, is dus werkelijk gewin. Korter afstand vergemakkelijkt de concurrentie met de Engelsche kolen, vermeerdert het debiet en vergroot de winst der onderneming.

D'en afstand van d'e Brandewijnsbaai tot de verschillende havens als eenkeid aannemende, blijkt, dat die afstand bij afvoer via de Oostkust wordt overtoffen:

$\begin{array}{llrrr}\text { naar Batavia } & \text { met } & 44 & \text { pCt. } \\ & \text { Samarang } & n & \mathbf{2 6} & n \\ n & \text { Soerábaja } & n & \mathbf{2 0} & n \\ & \text { Tjilatjap } & n & 54 & n \\ n & \text { Atjeh } & n & 101 & n \\ n & \text { Point de Galle } & n & \mathbf{5 6} & n\end{array}$

Daarentegen is de afstand van genoemde baai:

$\begin{array}{ll}\text { tot Singapore } & 73 \mathrm{pCt} \text {. } \\ \text { en } & \text { Hongkong } \\ \end{array}$

grooter dan de weg, welke de kolen bij afvoer oostwaarts naar die havens moeten afleggen.

Nu zullen juist de havens op Java de voornaamste en zekerste afnemers der Ombilienkolen zijn.

Voegt men hierbij de gunstige ligging der Brandewijnsbaai voor Sumatra's Westkust, voor Átjeh en Point de Galle, dan zal het wel geen nader betoog behoeven, dat de voordeelen van Moeära Kompeh voor het verkeer met Singapore en Hongkong hiertegen niet opwegen, te meer daar 't weinig waarschijnlijk is, dat men de Ombilienkolen te Hongkong een vaste markt zal kunnen verzekeren. $(*)$

(*) Benvondige becljfering leert, dat - bij een kolendebiet in de verschillende havens, als boven werd geraamd - het transportmoment, bij afvoer via de Oostkust 46,775,000 ton-nijl grooter is, dau bij afroer over de Brandewijnsbait: Hieruit volgt 0 . a.

1. dat, bij een scheepsuracht van slechts 0,5 cent per ton-mijl (en dit is zeer 
Men mag bovendien niet vergeten, dat men voor het kolenvervoer van de Brandewijnsbaai naar de verschillende havens steameolliers met 60 decimeters diepgang kan bezigen, terwijl aan de Djambimonden slechts transportschepen met hoogstens 40 decimeters diepgang bruikbaar zijn, welke dan nog alleen bij hoog water kunnen binnenkomen. Een onvermijdelijk gevolg hiervan is, dat men bij afvoer via Moeära Kompeh naar evenredigheid hooger vracht zal moeten betalen.

Tot hiertoe werd uitsluitend het kolenvervoer beschouwd en geen rekening gehouden met de overige omstandigheden, welke de kwestie beheersehen.

Gewichtige overwegingen van verschillenden aard, allen ontleend aan den toestand van land en volk, pleiten voor een spoorweg van het kolenveld naar de Westkust.

De naar de Brandewijnsbaai ontworpen spoorweg gaat door de IX Kota's en rakelings langs Kampong Solok, middelpunt der onderafdeeling van dien naam; de weg doorsnijdt verder de XX Kota's, de Batipoe en X Kota's en gaat midden door de onderafdeelingen Kajoetanam en Ommelanden van Padang naar de hoofdplaats.

De spoorweg komt bovendien, dank zij den grooten weg van Fort y/d. Capellen naar het meer van Singkarah, ten goede aan het schoonste gedeelte van Tanah Datar en voorziet bovendien in het verkeer tusschen Padang aan de eene en Agam met de $\mathrm{L}$ Kota's aan de andere zijde.

De waarde der richting blijkt o. a. uit de volgende bevolkingscijfers :



weinig), afvoer via de Westkust jaarlijks ongeveer $f 235,000$ besparing op de scheepsvracht geeft.

2. dat, wat de vracht betreft, beide richtingen gelijke waarde hebbeu, wanueer - bij overigens onveranderde omstandigheden - de afzet te siugajore tot 160,000 ton 's jaars stijgt.

beze becijfering, waraau men geeu absolute waarde wenscht toe te keonen, strekke tot uadere toelichting van het bovengezegde. 
overgebracht 185,000 zielen.

bovendien deelen in het verkeer met de hoofdplaats :

onderafd. Pajakombo met 103.000 zielen

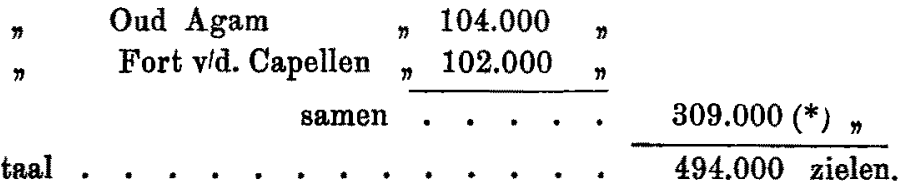

Deze bevolking is onregelmatig verdeeld. Oud Agam, de onderafdeeling Fort v/d. Capellen, de Batipoe, de X Kota's en Pajakombo hebben grooter bevolkingsdichtheid dan de meeste Europeesche landen en dan verscheidene onzer provinciën.

De bevolking van deze doon de natuur zoo rijk gezegende landstr eek leeft grootendeels van landbouw en veeteelt, en drijft voor een klein deel ook handel.

Alle berghellingen, zoowel die van den Merapi en den Sagoe, als die van den Talang en den Singalang, zijn aan den voet ruim voorzien van levend water en tot sawah's ingericht. Een hoogere zône is met koffietuinen bedekt en de tusschengelegen strook met suikerriet of andere cultuurgewassen beplant.

De gambier- en tabaks-cultuur, de teelt van Europeesche voodingsgewassen, de veefokkerij enz. zijn gewichtige bestanddeelen van het bedrijf van den inlander. Al dragen ze slechts voor een klein deel bij. tot den uitvoer over zee, zoo zijn ze toch voldoende, om te voorzien in de eigen behoeften van de landstreek.

In vroegere jaren was zelfs de rijstuitvoer van Padang naar andere streken van den Archipel niet onbeduidend en zou o. a. in 1862133,000 pikols hebben bedragen. De uitvoer heeft van 1868 tot 1871 - ten gevolge van de ziekte, wolke den veestapel teisterde - geheel opgehouden, maar is sinds dien tijd, hoewel langzaam, toenemend.

Van een Nederlandsch standpunt komt de koffieteelt - grootendeels gouvernements-cultuur - het meest in aanmerking. Van 1899 werd in de verschillende pakhuizen gemiddeld 113,204 pikol koffie 's jaars afgeleverd; in 1870 bedroeg de opbrengst zelfs 151,675 pikol.

De gouvernements-koffie, thans over Padang Pandjang naar de hoofdplaats gebracht, zal later per spoorweg naar Padang gaan,

(*) De spoorweg zal bovendien ecnig voordecl geven ann de 31000 inwoners dér anderafdecling Priaman, 
waardoor ongeveer $\int 190,000$ aan transportkosten wordt bespaard.

Op de oostelijke bergflanken van het Barisan-gebergte, voornamelijk van den Talang tot tegen den Singalang liggen verscheidene duizendtallen bouws woeste, nog met urwald bedekte gronden, uitstekend geschikt voor de koffiecultuur.

Sinds enkele jaren zijn enkele particuliere koffie-ondernemingen tot stand gebracht. De tot heden door haar aan de markt gebrachte hoeveelheid is nog niet aanzienlijk, maar zij zijn nog in de geboorte. Het aantal ondernemingen en de productie der bestaande ontginningen vermeerderen van jaar tot jaar.

De particuliere koffie zal later voor een goed deel per spoorweg haar weg naar de haven nemen.

De spoorweg zal boviendien nog in een vrij belangrijk verkeer voorzien. De afvoer door de Kloof der Aneh bedragt - na aftrek der koffie - gemiddeld 55,000 pikol 's jaars; deze hoeveelheid zal later zoo niet geheel, dan toch grootendeels over den spoorweg naar Padang gaan.

Men moet voorts niet over het hoofd zien, dat in de Bovenlanden en tusschen deze residentie en de hoofdplaats een levendig personen-verkeer plaats rindt. De pássars van Solok, Singkarah en Batipoe worden steeds goed bezocht, terwijl men de bezoekers der groote weekmarkten van Padang Pandjang, Fort de Kock en Pajakombo bij duizendtallen kan tellen.

Ook in dit personenverkeer zal de spoorweg deelen.

Wanneer men aanvankelijk besluit tot aanleg van den spoorweg Kolenveld-Padang Pandjang-Padang-haven, en in later jaren overgaat tot den bouw van een zijtak Padang Pandjang-Fort de Kock-Pajakombo (61 kilometer), dan is daarmede geheel voorzien in de behoefte aan verbeterde gemeenschap der Padangsche Boven- en Benedenlanden. Deze spoorwegen zullen de voornaamste centra van bevolking en productie onderling en met de hoofdplaats verbinden.

Een spoorweg van het Kolenveld naar Si Tioen doorsnijdt daarentegen eerst de zwak bevolkte onderafdeeling VII Kota's, en wel het minst volkrijke deel dier landstreek, en daarna het rijkje \$i Goentoer.

De totale bevolking van het rijk Bjambi wordt in de koloniale verslagen op 76,000 zielen geschat, verspreid over een oppervlakte grooter dan Nederland.

Een groot deel dier lieden woont langs of nabij de rivier. Volgens den heer S. S. wordt ${ }_{n}$ de bevolking van de oevers der Batang ${ }_{n}$ Hari van Moeära Djoedjoeän tot aan Moeära Kompeh op 22,500, 
"die aan de Kompeh en de Bating Hari van Moeära Kompeh "tot aan hare verschillende uitmondingen op 5250 zielen ge"schat." $(*)$

De bewoners dezer grootendeels lage gronden beoefenen slechts den landbouw, om in eigen behoeften te voorzien; zij leven verder van de vischvangst en nabij de grenzen der Padangsche Bovenlanden van de veeteelt. Het land levert voor den uitvoer slechts boschproducten, welke te Moeära Kompeh worden ingescheept.

De groote uitgestrektheid gronds tusschen het kolenveld on het Oosterstrand heeft dus tegenwoordig geringe beteekenis en bevat geen enkel element, om een transportweg te voeden. Het nieuwe vervoermiddel zal dus uitsluitend den kolenafvoer dienen, alleen daarvoor bestaan, maar ook geen andere bronnen van inkomst hebben.

Voorzeker zal de bevolking, in het stroomgebied der Djambi verspreid, toenemen, wanneer het Nederlandsch gezag daar ongestoord wordt erkend, maar die toename zal uiterst langzaam zijn.

De europeesche ondernemer zal niet spoedig besluiten, om zijn kapitaal en kennis in het stroomgebied der Djambi to wagen, zoolang elders uitstekende gronden, te midden van een dichte en betrekkelijk beschaafde bevolking hem noodigen, om gewassen voor de europeesche markt te teelen.

Men heeft voorloopig met den bestaanden toestand te rekenen en moet niet vergeten, dat voor aanleg van den spoorweg Kolenveld-Si Tioen en den bouw der langs de rivier en te Moeära Kompeh gevorderde werken, een groot aantal werkkrachten noodig zijn, welke men, als niet ter plaatse voorhanden, van elders moet aanvoeren.

De spoorweg naar de Indische Zee zal de haven nabij Padang tot terminus hebben; de afvoerweg nạar de Oostkust zal te Moeära Kompeh eindigen.

Padang, met ongeveer 25,000 inwoners is, in vergelijking van Moeära Kompeh, een handelsplaats van groote beteekenis; dit blijkt o. a. uit de volgende cijfers $(\dagger)$.

(*) Zie Bericht no. 2 bldz. 25.

(†) Deze cijfers, omtrent de handelsbeweging (de eenigen, waarover men, wat de Oostkust betreft, kon begclikken) hebben betrekking op de waarde der inen nitgeroerde "koopmanschappen " en zijn ontleend aan de Koloniale Verslagen.

$Z_{i j}$ verachilleen eenigszins met de opgaren van mijn Rapport (t, a. pl. bldz. 56.) 
4. Handels beweging.

\begin{tabular}{|c|c|c|c|c|}
\hline \multirow{2}{*}{ H A V E N. } & \multicolumn{2}{|c|}{ INTOER. } & \multicolumn{2}{|c|}{ UITVOER. } \\
\hline & 1871. & 1872. & 1871. & 1872. \\
\hline Padang . . . . & $f 4,972,258$ & $f 4,302,214$ & $f 9,302,495$ & $f 6,076,544$ \\
\hline Moeära Kompeh & 252,287 & 307,105 & 219,560 & 444,910 \\
\hline
\end{tabular}

B. Scheepraartbeweging.

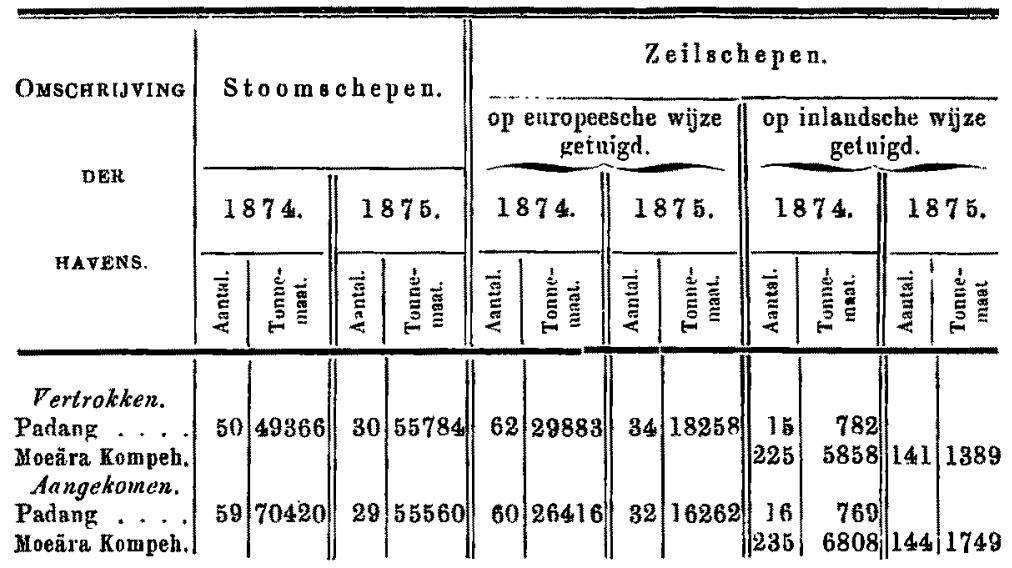

Nadere toelichting dezer sterk sprekende ejfers is overbodig.

De scheepvaartbeweging to Mooära Kompeh zal toenemen, to meer nu de stoombooten der Ned. Ind. Stoomvaartmaatschappij die plaats geregeld éénmaal 's maands bezoeken, maar hiertegenover staat, dat ook de stoomvaartlijnen langs Sumatra's Westkust zijn uitgebreid sinds de jaren, waarop bovenstaande gegevens betrekking hebben.

Havenaanleg in de Brandewijnsbaai zal, wanneer daar goede steenkolen tegen lagen prijs verkrijgbsar zijn, een nieuwe prikkel wezen voor de Nederlandsche stoomers om op de heen- en terugreis een haven aan te doen, waar reeds andere handelsbelangen ze roepen. Die belangen zullen te Moeära Kompeh - geheel buiten den handelsweg - nimmer bestaan.

Afvoer naar de Indische Zee of naar de Oostkust nogmaals tegen elkaar stellende, verkrijgt men in het eerste geval:

een spporweg door een zeer vruchtbare en goed bevolkte land- 
streek met een half milliocn zielen, langs of nabij dien weg, welke niet alleen van het kolentransport zal bestaan, maar bovendien een belangrijk producten-vervoer zal verkrijgen en in een niet gering te schatten personenverkeer zal voorzien. De spoorweg geeft - als onafscheidelijk aan den aanleg verbonden - een haven aan de eerste handelplaats van Sumatra en vereenigt de hoofdplaats met de voornaamste afdeelingen van het Gouvernement. Het nieuwe transportmiddel geeft daarenboven onmiddellijk belangrijke besparing op den afvoer der gouvernementskoffie en op verschillende uitgaven, verbonden aan het bestuur van het Gewest. De reeds lang voorgenomen verplaatsing van het militair kommandement van Padang naar Fort de Kock zal door spoorwegaanleg zoo niet mogeljk, dan toch gemakkelijker worden.

Bij afvoer oostwaarts daarentegen een transportweg, die weinig minder, hoogstwaarschijnlijk meer zal kosten, dan een spoorweg naar de Brandewijnsbaai. De weg veroorlooft niet om de Ombilienkolen op de voornaamste plaatsen van verbruik tegen minder prijs te leveren, dan bij afvoer naar de Indische Zee, maar noodzaakt zelfs, om dien prijs te verhoogen, voor zooveel Java, Atjeh en Point de Galle betreft. Spoorweg en rivier voeren door een woest, nagenoeg onbewoond terrein. De transportweg moet uitsluitend van het kolenvervoer bestaan, geen landbouwprodukten zullen langs dien weg het Oosterstrand bereiken, geen noemenswaardig personenverkeer is daar denkbaar.

Ongetwijfeld is het Gouvernement Sumatra's Westkust, en meer bepaald de residentie Padangsche Bovenlanden, na Java het belangrijkste gedeelte van den Indischen Archipel. Die landstreek drangt reeds thans meer bij tot de opbrengst van Nederlandsch Indie, dan de meeste residenties van Java.

Het gewest heeft echter behoefte aan verbetering der transportmiddelen; Padang eischt dringend betere gemeenschap met hare reede, wat slechts door havenaanleg is te bereiken.

Met een afvoerweg van het Kolenveld naar de Oostkust worden de Padangsche Boven- en Benedenlanden niet gebaat. De juistheid van het reeds meermalen en van verschillende zijde geuitte ${ }_{n}$ zonder "kolenontginning geen spoorwegaanleg" is nog door niemand in twijfel getrokken.

Worden de kolen niet naar de Indische Zee, maar naar de monden der Djambi gevoerd, dan is Sumatra's Westkust voor immer tot een stationnairen toestand gedoemd.

Daarentegen zal spoorwegaanleg naar de Brandewijnsbaai, zoo 
goed als overal elders, ook op Sumatra's Westkust krachtig medewerken tot vermeerdering van de volkswelvaart.

Naarmate de prikkel tọt den arbeid grooter wordt, zal de Maleische landbouwer zijn bedrijf intensiever drijven; hierdoor zal de productie vermeerderen en de uitvoer toenemen.

Als onmiddellijk gevolg hierrạn zal de invoer, voornamelijk dịe van lijnwaden, toenemen en Padang's handel een nieuw tijdperk van bloei tegemoetgaan.

De opmerkingen der voorgaande bladzijden kunnen in 't kort als volgt worden saamgevat:

1. De Djambi kan - volgens de thañs voorhanden gegevens niet als afvoerweg der Ombilien-kolen in aanmerking komen.

2. Is afvoer langs de Djambi mogelijk, dan zal een derwaarts te maken transportweg, zoo niet meer, dan toch nagenoeg evenveel kosten dan een spoorweg viâ Padang Pandjang naar de Brandewijnsbaai met havenaanleg aldaar.

3. Afvoer oostwaarts zal de voor Java, Atjeh on Point de Galle (de voornaamste markten der Ombilienkolen) bestemde kolen met hooger transportkosten bezwaren, dan bij afvoer naar de Westkust.

4. terwijl de transportweg naar de monden der Djambi uitsluitend van het steenkolenvervoer zal moeten bestaan, kan men op den spoorweg naar de Indische zee een vrij belangrijk goederenen personen-verkeer, met niet onaanzienlijke directe baten, verwachten.

5. het welbegrepen belang van Sumatra's Westkust eischt spoorwegaanleg naar de Brandewijnsbaai.

In deze bladzijden is opnieuw de aandacht gevestigd op den grooten schat, welke nog ginds begraven ligt en wordt de belangrijke vraag $n$ kolenafvoer Oost- of Westwaarts ?" aan de ernstige overweging van alle belangstellenden aanbevolen.

Het met dit schrijven beoogde doel is bereikt, wanneer zich daardoor een meer bevoegde tot behandeling der kwestie opgewekt gevoelt.

Breda. J. L. Clujusenaer.

NASCHRIFT. - Na het zetten der voorgaande bladzijden verscheen in de Slaalscourant dd. 21 Mei Il. no. 119 het "Rapport van " den resident van Palembang betreffende een opneming yan de „ rivier Batang Hari tot aan de o.ostelijke grens van Djambi." 
De reis van den resident Pruijs van der Hoeven, in dit rapport beschreven, heeft belangrijke gegevens verstrekt omtrent de bevaarbaarheid der Batang Hari, terwijl de in Februari verrichte plaatsbepalingen verbetering der bestaande kaarten veroorloven.

De mededeelingen van den Hr. Pr. v. d. Hoeven verzwakken in geen enkel opzicht de boven ontwikkelde opmerkingen, maar versterken mij integendeel in de meening, dat van steenkolenafvoer langs de Djambi bezwaarlijk siprake kan zijp.

De "Barito" had te kampen met al de bezwaren, onafscheidelijk verbonden aan de vaart op een snel stroomende rivier, welke buiten haar oevers getreden - een zeer onregelmatig stroombed heeft. Deze bezwaren verbieden het vormen van lange sleepoonvooien en noodzaken tat het gebruik van krachtige sleepbooten; de geringe diepte der rivier in den droogen moesson eischt daarentegen weinig diepgaande stoomsleepers.

De Hr. Pr. v. d. H. heeft borendien aangetoond, dat de spoorweg van het Kolenveld naar de Batang Hari niet tot Si Tioen, zooals de ingenieur Veth vermoedde, maar verder benedenwarts moet worden voortgezet; immers heeft boven Tandjong geen prauwvaart meer plaats. Hoogstwaarschijnlijk zal het veryoer te water eerst bij Semalidoe (volgens den resident Pr. v. d. H. 362 Eng. mijl van den mond verwijderd) een aanvang kunnen nemen.

De spoorweg wordt dus in elk geval langer, het vervoer naar straat Malakka derhalve kostbaarder, dan boven werd ondersteld, een en ander geheel ten voordeele der daar ontwikkelde meeningen.

J. L. C. 